\title{
Influence of toxic endophyte-infected tall fescue on the prevalence of $E$. coli 0157:H7 from ruminants, a review
}

\author{
M.L. LOOPER ${ }^{1}$, T.S. EDRINGTON ${ }^{2}$, T.R. CALLAWAY ${ }^{2}$, R. FLORES ${ }^{3}$, \\ G.E. AIKEN ${ }^{4}$, J.M. BURKE ${ }^{1}$ and C.F. ROSENKRANS, JR. ${ }^{3}$ \\ ${ }^{1}$ USDA-ARS, Dale Bumpers Small Farms Research Center, Booneville, AR, USA \\ ${ }^{2} U S D A-A R S$, Food and Feed Safety Laboratory, College Station, TX, USA ${ }^{3}$ Department of Animal Science, University of Arkansas, \\ Fayetteville, AR, USA ${ }^{4}$ USDA-ARS, Forage Animal Production Research Unit, Lexington, KY, USA \\ mlooper@spa.ars.usda.gov
}

\begin{abstract}
Ruminants consuming toxic endophyte-infected $(\mathrm{E}+)$ tall fescue are exposed to ergot alkaloids that usually result in a malady of problems identified as fescue toxicosis. Grazing studies investigating the effects of $\mathrm{E}+$ tall fescue on the prevalence of E. coli O157:H7 from naturally-infected cattle have not been consistent. Further, in vitro studies with selected ergot alkaloids did not affect growth of E. coli O157:H7. Dietary stressors usually associated with E+ tall fescue consumption did result in increased faecal shedding of E. coli $0157: \mathrm{H} 7$ from sheep experimentally-inoculated. Animal species, animal model (naturally vs experimentally-infected), environmental conditions, type of diet, and length of exposure to E+ tall fescue may influence the association between grazing $\mathrm{E}+$ tall fescue and E. coli $\mathrm{O} 157: \mathrm{H} 7$ shedding. A better understanding of how $\mathrm{E}+$ tall fescue influences shedding of E. coli O157:H7 from ruminants will aid in the development of management strategies for onfarm pathogen control.
\end{abstract}

Keywords: cattle, E. coli O157:H7, sheep, tall fescue

\section{Introduction}

Approximately $70 \%$ of the more than 20 million hectares of tall fescue (Festuca arundinacea (Schreb), syn, Lolium arundinaceum (Schreb.) Darbysh) grown in the southeastern United States is infected with the toxic endophyte fungus, Neotyphodium coenophialum, which produces numerous ergot alkaloids (Shelby \& Dalrymple 1987). Ruminants grazing toxic endophyte-infected $(\mathrm{E}+)$ tall fescue generally exhibit various stressful signs of fescue toxicosis (Hoveland et al. 1983; Paterson et al. 1995). It is possible that stress may cause ruminants to become more susceptible to pathogenic bacteria such as $E$. coli O157:H7 (Fitzgerald et al. 2003; Looper et al. 2006a). Reduced dry matter intake is common in ruminants consuming $\mathrm{E}+$ tall fescue (Paterson et al. 1995; Parish et al. 2003), and alterations in the diet may influence faecal shedding of pathogenic bacteria from ruminants (Callaway et al. 2003).

Studies have generally focused on faecal shedding of $E$. coli O157:H7 from grain-fed cattle due to the possibility of contaminated beef entering the human food supply (Elder et al. 2000; Smith et al. 2001); however, grazing cattle are also infected with E. coli O157:H7 (Laegreid et al. 1999; Riley et al. 2003; Dunn et al. 2004). Investigation of how consumption of $\mathrm{E}+$ tall fescue influences the prevalence of $E$. coli $\mathrm{O} 157: \mathrm{H} 7$ from ruminants is necessary to reduce the number of animals shedding pathogenic bacteria on entering the feed-yard or processing facility. This review examines a series of recent experiments that our laboratories have conducted to investigate the influence of $\mathrm{E}+$ tall fescue on shedding of $E$. coli $\mathrm{O} 157: \mathrm{H} 7$ from ruminants.

\section{Methods}

The Animal Care and Use Committees at the USDA-ARS, Food and Feed Safety Laboratory and (or) the USDA-ARS, Dale Bumpers Small Farms Research Center approved care, use, and handling of animals in the following experiments.

\section{Influence of $\mathrm{E}+$ tall fescue on $E$. coli $0157: \mathrm{H} 7$ from naturally-infected cattle}

In our initial experiment, faecal samples were collected from Angus $x$ Hereford cows $(n=49)$ and their spring-born calves $(n=45)$ grazing $E+$ tall fescue or endophyte-free (E-) tall fescue during summer. Our objectives were to examine 1) effects of forage type on shedding of E. coli O157:H7 from naturallyinfected cattle, and 2) influence of $E$. coli shedding from the cow on the incidence of $E$. coli shedding from the calf. Faecal samples were collected at 0700 on each collection date (5 August and 26 August); mean ambient temperature and relative humidity at time of faecal collections were $27^{\circ} \mathrm{C}$ and $77 \%$, respectively.

A second grazing experiment at two locations was conducted to compare the prevalence of faecal shedding of E. coli $\mathrm{O} 157: \mathrm{H} 7$ in growing beef cattle consuming different forage diets. At location 1 , faecal samples were collected thrice from steers grazing either $\mathrm{E}+$ tall fescue or common bermudagrass (Cynodon dactylon; $\mathrm{CB})$. Steers grazing E + tall fescue were confined to a dry-lot pen and fed CB hay ad libitum for 10 days following the E+ grazing period. At location 2, faecal samples were collected twice from steers grazing $\mathrm{E}+$ or novel endophyte-infected [NE; HiMag tall fescue with strain 4 and marketed as the variety ArkPlus ${ }^{\mathrm{TM}}$ from 2002 to 2004 (West et al. 1998)].

\section{Influence of selected ergot alkaloids on growth of $E$. coli 0157:H7 in vitro}

Three commercially available ergot alkaloids (dihydroergotamine, ergonovine, and ergotamine) that are found in E+ tall fescue were evaluated for their effects on the growth of two strains of $E$. coli $\mathrm{O} 157: \mathrm{H} 7$. A range of concentrations of each ergot alkaloid (10 pM, $1 \mathrm{nM}, 100 \mathrm{nM}, 10 \mu \mathrm{M}, 1 \mathrm{mM}$ and a methanol control) were added to pure and mixed ruminal fluid cultures of $E$. coli O157:H7.

\section{Influence of $\mathrm{E}+$ tall fescue seed on $E$. coli $0157: \mathrm{H} 7$ from experimentally-inoculated ewes}

Ewes were acclimated to the experimental diet (cracked corn substituted for fescue seed) for 7 days before initiation of the experiment and then fed diets containing either high endophyteinfected (HI-E; $0.75 \mathrm{mg}$ ergovaline $/ \mathrm{kg}$ ) or low endophyteinfected (LO-E; $0.11 \mathrm{mg}$ of ergovaline $/ \mathrm{kg}$ ) tall fescue seed $(50 \%$, as-fed basis) for 7 days. Ewes were inoculated with antibioticresistant selected $E$. coli $\mathrm{O} 157: \mathrm{H} 7$ on day 1 of feeding treatment, 
and faecal shedding of inoculated pathogens was monitored daily (day 2 to 6 ). On day 7 , ewes were weighed, euthanased, and tissues and contents sampled from the ileum, caecum, and rectum for quantitative enumeration of E. coli $\mathrm{O} 157: \mathrm{H7}$. Urine also was collected at euthanasation to determine total ergot alkaloid concentrations via immunoassay (Hill et al. 2000).

\section{Bacterial culture and isolation}

In all experiments, an immunomagnetic separation technique was used to isolate $E$. coli $\mathrm{O} 157: \mathrm{H} 7$. Faeces $(10 \mathrm{~g})$ were enriched in $90 \mathrm{ml}$ of gram-negative broth containing vancomycin $(8 \mu \mathrm{g} /$ $\mathrm{ml})$, cefixime $(0.5 \mu \mathrm{g} / \mathrm{ml})$, and cefsoludin $(10 \mu \mathrm{g} / \mathrm{ml})$. Following incubation for 6 hours at $37^{\circ} \mathrm{C}, 20 \mu \mathrm{l}$ of anti-E. coli $\mathrm{O} 157: \mathrm{H} 7$ antibody-labeled paramagnetic beads (Neogen Corp., Lansing, MI, USA) were added to $1 \mathrm{ml}$ volumes of the above enrichments, mixed and washed thrice in $1 \mathrm{ml}$ of phosphate-buffered saline (PBS) with $0.05 \%$ Tween 20 . Fifty microliters of the resulting suspension was plated on CHROMagar ${ }^{\mathrm{TM}}$ O157 (DRG International, Mountain Side, NJ, USA) plates (containing 2.5 $\mu \mathrm{g} / \mathrm{ml}$ potassium tellurite) and incubated overnight at $37^{\circ} \mathrm{C}$. Pink colonies exhibiting E. coli $\mathrm{O} 157: \mathrm{H} 7$ colony morphology were resuspended in PBS and confirmed as E. coli O157:H7 using the Reveal ${ }^{\circledR}$ microbial screening test (Neogen Corp., Lansing, MI, USA).

\section{Results and Discussion}

\section{Influence of $\mathrm{E}+$ tall fescue on $E$. coli $\mathrm{O} 157: \mathrm{H} 7$ from naturally- infected cattle}

Overall, incidence of E. coli $\mathrm{O} 157: \mathrm{H} 7$ shedding averaged $8.4 \%$ and $7.6 \%$ for calves and cows, respectively. The percentage of cows positive for E. coli $\mathrm{O} 157: \mathrm{H} 7$ was lower $(\mathrm{P}<0.05)$ in cows grazing $\mathrm{E}+$ than the percentage of cows grazing $\mathrm{E}-(1.8 \%$ vs $17 \%$ for E+ and E- cows, respectively). Likewise, the percentage of calves shedding $E$. coli $\mathrm{O} 157: \mathrm{H} 7$ tended $(\mathrm{P}=0.11)$ to be reduced in $\mathrm{E}+$ calves $(4.3 \%)$ compared with E- calves $(13.9 \%)$. The presence of E. coli $\mathrm{O} 157: \mathrm{H} 7$ in the faeces of the cow did not influence $(\mathrm{P}>0.10)$ shedding of the bacterium from the calf. These preliminary results suggested that consumption of $\mathrm{E}+$ tall fescue might reduce the incidence of faecal shedding of $E$. coli O157:H7 in naturally-infected cattle (Looper et al. 2003).

Sixteen percent of steers were positive for E. coli $\mathrm{O} 157: \mathrm{H} 7$ at location 1 in the second grazing experiment. Faecal shedding of E. coli $\mathrm{O} 157: \mathrm{H} 7$ was reduced in $\mathrm{E}+$ tall fescue steers fed $\mathrm{CB}$ hay compared with steers continuously grazing $\mathrm{CB}$ at location 1 . At location 2, the percentage of steers positive for E. coli O157: $\mathrm{H} 7$ was $3.3 \%$. Consumption of $\mathrm{E}+$ tall fescue did not influence faecal shedding of E. coli O157:H7 at either location; however, hay feeding of steers previously grazing $\mathrm{E}+$ tall fescue did reduce the prevalence of E. coli O157:H7 (Looper et al. 2006b).

Prevalence of faecal shedding of E. coli O157:H7 from naturally-infected cattle in both experiments was highly variable ranging from $1.8 \%$ to $17 \%$. Further, influence of $\mathrm{E}+$ tall fescue on the prevalence of $E$. coli $\mathrm{O} 157: \mathrm{H} 7$ was inconsistent; however, altering the diet by feeding hay after grazing might be a possible management strategy to reduce fecal shedding of E. coli O157: H7 (Looper et al. 2006b).

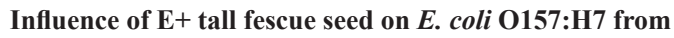 experimentally-inoculated ewes}

Ewes fed HI-E had lower $(\mathrm{P}<0.001)$ dry matter intake (DMI) than ewes fed LO-E. There was a tendency $(\mathrm{P}=0.06)$ for HI-E ewes to lose weight and LO-E ewes to gain weight during the experiment. Urinary ergot alkaloids were increased $(\mathrm{P}<0.001)$ in ewes fed HI-E compared with the LO-E ewes. Faecal shedding of $E$. coli $\mathrm{O} 157: \mathrm{H} 7$ tended $(\mathrm{P}=0.06)$ to be increased in HI-E ewes compared with LO-E ewes (Fig. 1). Population of E. coli O157: $\mathrm{H} 7$ in luminal contents from the ileum, caecum, and rectum did not differ $(\mathrm{P}>0.36)$ between treatments. Treatment did not influence $(\mathrm{P}=0.30)$ the occurrence of $E$. coli $\mathrm{O} 157: \mathrm{H} 7$ in caecal or rectal tissues; however, ileal tissues from HI-E ewes tended $(\mathrm{P}=0.12)$ to have an increased incidence of $E$. coli $\mathrm{O} 157: \mathrm{H} 7$.

Feeding HI-E tall fescue seed for 7 days induced signs of fescue toxicosis including decreased DMI, increased urinary concentrations of total ergot alkaloids, and reduced body weights. Ewes fed HI-E tall fescue seed diets tended to shed more antibiotic-resistant E. coli $\mathrm{O} 157: \mathrm{H} 7$ in their faeces and tended to have an increased incidence of antibiotic-resistant $E$. coli O157: H7 in their ileum than LO-E ewes (Looper et al. 2006a).

\section{Influence of selected ergot alkaloids on growth of $E$. coli O157: $\mathrm{H} 7$ in vitro}

No differences $(\mathrm{P}>0.10)$ were found in growth rates in pure culture of $E$. coli $\mathrm{O} 157: \mathrm{H} 7$ when comparing increasing concentrations of the same ergot alkaloid or when comparing different ergot alkaloids. Similarly, increasing ergot alkaloid concentrations had no effect $(\mathrm{P}>0.10)$ on colony-forming units for E. coli $\mathrm{O} 157: \mathrm{H} 7$ after incubation in mixed ruminal fluid. There was minimal, if any, effect on the growth of E. coli O157:H7 from these three ergot alkaloids. Ergot alkaloids, at the various concentrations used in this experiment would have included the range of concentrations that occur in the rumen of cattle grazing E+ tall fescue. Other factors such as different ergot alkaloids (i.e. ergovaline), exposure to a combination of alkaloids, characteristics of the grazed forage, or management strategies may influence faecal shedding of $E$. coli $\mathrm{O} 157: \mathrm{H} 7$ in cattle grazing $\mathrm{E}+$ tall fescue (Looper et al. 2004). Currently, experiments are being conducted that include the alkaloid, ergovaline, as well as combinations of these four alkaloids to more closely mimic the whole plant exposure that grazing ruminants would experience.

\section{Conclusions}

Differences in faecal shedding patterns between experimentallyinoculated animals and naturally infected animals may explain variations among our studies. Shedding of E. coli O157:H7 in naturally-infected animals is sporadic, with an animal testing positive at one sample collection and negative at the subsequent collection (Callaway et al. 2004). Length of exposure to the toxic effects of $\mathrm{E}+$ tall fescue also may attribute to differences between studies. Ewes were exposed to a diet containing E+ seed for 7 days (Looper et al. 2006a) while cattle utilised in our grazing experiments (Looper et al. 2003, 2006b) were exposed to $\mathrm{E}+$ tall fescue from 87 days to approximately 2 years. It is possible that animals may become acclimated to the toxic effects of fescue after prolonged exposure (Spiers et al. 2005). Differences in diets (total mixed ration vs grazing) also may have contributed to differences in faecal shedding among experiments. Sudden alterations in diet, specifically a shift from concentrate to forage feeding may decrease pathogen shedding (Callaway et al. 2003) which is similar to our results (Looper et al. 2006b). Possible differences in the pattern of faecal shedding between cattle and sheep also may have influenced results within studies. Management strategies that prevent livestock from grazing E+ tall fescue and (or) alleviate dietary stressors (i.e. reduced DMI) associated with consumption of $\mathrm{E}+$ tall fescue before entry into the feed-yard or harvest facility may reduce faecal shedding of pathogenic bacteria from livestock. 
Figure 1 Faecal shedding (colony-forming units, cfu $\left(\log _{10}\right) / g$ faeces) of $E$. coli 0157:H7 from ewes experimentally-inoculated with E. coli $\mathrm{O} 157: \mathrm{H} 7$ and fed diets of high endophyte-infected (HI-E) or low endophyteinfected (LO-E) tall fescue seed; treatment diet effect $(P=0.06$; standard error $=0.30)$; ${ }^{a, b}$ day effect $(P<0.001)$; treatment $x$ day interaction $(P=0.18)$ (Looper et al. 2006a).

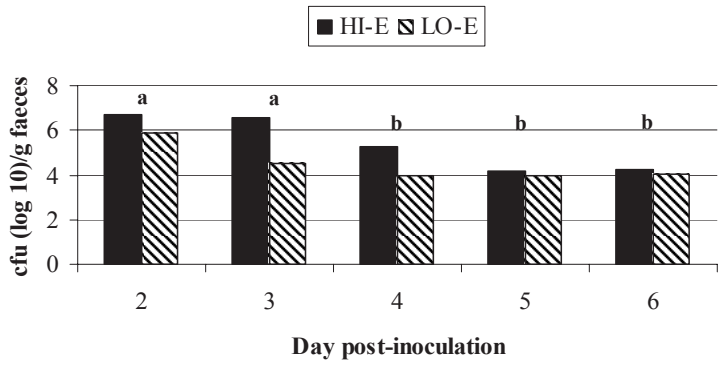

\section{ACKNOWLEDGEMENTS}

The authors gratefully acknowledge L. Huddleston, W. Jackson, G. Robson, and D. Jones, USDA-ARS, for technical assistance and daily animal management; and D. Kreider, M. Lamb, S. Reiter, and Feed Mill personnel, University of Arkansas, for technical assistance.

\section{REFERENCES}

Callaway, T.R.; Anderson, R.C.; Edrington, T.S.; Genovese, K.J.; Bischoff, K.M.; Poole, T.L.; Jung, Y.S.; Harvey, R.B.; Nisbet, D.J. 2004. What are we doing about Escherichia coli O157:H7 in cattle? Journal of Animal Science 82(E. Suppl.): E93-E99.

Callaway, T.R.; Elder, R.O.; Keen, J.E.; Anderson, R.C.; Nisbet, D.J. 2003. Forage feeding to reduce preharvest Escherichia coli populations in cattle, a review. Journal of Dairy Science 86: 852-860.

Dunn, J.R.; Keen, J.E.; Del Vecchio, R.; Wittum, T.E.; Thompson, A.A. 2004. Escherichia coli O157:H7 in a cohort of weaned, preconditioned range beef calves. Journal of Food Protection 67: 2391-2396.

Elder, R.O.; Keen, J.E.; Siragusa, G.R.; Barkocy-Gallagher, G.A.; Koohmaraie, M.; Laegreid, W.W. 2000. Correlation of enterohemorrhagic Escherichia coli $\mathrm{O} 157$ prevalence in feces, hides, and carcasses of beef cattle during processing. Proceedings of the National Academy of Science USA 97: 2999-3003.

Fitzgerald, A.C.; Edrington, T.S.; Looper, M.L.; Callaway, T.R.; Genovese, K.J.; Bischoff, K.M.; McReynolds, J.L.; Thomas, J.D.; Anderson, R.C.; Nisbet, D.J. 2003. Antimicrobial susceptibility and factors affecting the shedding of $E$. coli O157:H7 and Salmonella in dairy cattle. Letters in Applied Microbiology 37: 392-398.

Hill, N.S.; Thompson, F.N.; Stuedemann, J.A.; Dawe, D.L.; Hiatt, III, E.E. 2000. Urinary alkaloid excretion as a diagnostic tool for fescue toxicosis in cattle. Journal of Veterinary Diagnostic Investigation 12: 210-217.

Hoveland, C.S.; Schmidt, S.P.; King, Jr., C.C.; Odom, J.W.; Clark, E.M.; McGuire,
J.A.; Smith, L.A.; Grimes, H.W.; Holiman, J.L. 1983. Steer performance and association of Acremonium coenophialum fungal endophyte on tall fescue pasture. Agronomy Journal 75: 821-824.

Laegreid, W.W.; Elder, R.O.; Keen, J.E. 1999. Prevalence of Escherichia coli $\mathrm{O} 157: \mathrm{H} 7$ in range beef calves at weaning. Epidemiology and Infection 123: 291-298.

Looper, M.L.; Edrington, T.S.; Flores, R; Burke, J.M.; Callaway, T.R.; Aiken, G.E.; Schrick, F.N.; Rosenkrans, Jr., C.F. 2006a. Influence of dietary endophyte-infected (Neotyphodium coenophialum) tall fescue (Festuca arundinacea) seed on fecal shedding of antibiotic-resistance selected Escherichia coli O157:H7 in ewes. Journal of Animal Science 85: doi:10.2527/jas.2006-410. Accessed online January 3, 2007.

Looper, M.L.; Edrington, T.S.; Flores, R.; Rosenkrans, Jr., C.F.; Nihsen, M.E.; Aiken,

G.E. 2006b. Prevalence of Escherichia coli O157:H7 and Salmonella in beef steers consuming different forage diets. Letters in Applied Microbiology 42: 583-588.

Looper, M.L.; Edrington, T.S.; Rosenkrans, Jr., C.F.; Schultz, C.L.; Callaway, T.R.;

Aiken, G.E.; Flores, R; Brauer, D.K. 2004. Effects of the ergot alkaloids dihydroergotamine, ergonovine, and ergotamine on the growth of Escherichia coli O157:H7 and Salmonella in vitro. \#503 In: Proceedings of the $5^{\text {th }}$ International Symposium on Neotyphodium/Grass Interactions, Fayetteville, Arkansas.

Looper, M.L.; Rosenkrans, Jr., C.F.; Aiken, G.E.; Edrington, T.S. 2003. Escherichia coli and Salmonella in beef cattle grazing tall fescue. Arkansas Agriculture Experiment Station Report 509: 58-60.

Parish, J.A.; McCann, M.A.; Watson, R.H.; Hoveland, C.S.; Hawkins, L.L.; Hill, N.S.; Bouton, J.H. 2003. Use of nonergot alkaloid-producing endophytes for alleviating tall fescue toxicosis in sheep. Journal of Animal Science 81: 1316-1322.

Paterson, J.; Forcherio, C.; Larson, B.; Samford, M.; Kerley, M. 1995. The effects of fescue toxicosis on beef cattle productivity. Journal of Animal Science 73: 889-898.

Riley, D.G.; Gray, J.T.; Loneragan, G.H.; Barling, K.S.; Chase, Jr., C.C. 2003. Escherichia coli O157:H7 prevalence in fecal samples of cattle from a southeastern beef cow-calf herd. Journal of Food Protection 66: 1778-1782.

Shelby, R.A.; Dalrymple, L.W. 1987. Incidence and distribution of the tall fescue endophyte in the United States. Plant Diseases 71: 783-786.

Smith, D.; Blackford, M.; Younts, S.; Moxley, R.; Gray, J.; Hungerford, L.; Milton, T.; Klopfenstein, T. 2001. Ecological relationships between the prevalence of cattle shedding Escherichia coli $\mathrm{O} 157: \mathrm{H} 7$ and characteristics of the cattle or conditions of the feedlot pen. Journal of Food Protection 64: 1899-1903.

Spiers, D.E.; Evans, T.J.; Rottinghaus, G.E. 2005. Interaction between thermal stress and fescue toxicosis: animal models and new perspectives. pp. 243-270 In: Neotyphodium in coolseason grasses. Eds. Roberts C.A.; West, C.P.; Spiers, D.E. Blackwell Publisher, Ames, IA.

West, C.P.; Marlett, M.L.; McConnell, M.E.; Piper, E.L.; King, T.J. 1998. Novel endophyte technology: selection of the fungus. pp. 105-115 In: Molecular and cellular technologies for forage improvement. Eds. Brummer, E.C.; Hill, N.S.; Roberts, C.A., Crop Science Society of America, Madison, WI.. 